\title{
PENGARUH KOMPETENSI, INDEPENDENSI DAN INTEGRITAS AUDITOR TERHADAP KUALITAS AUDIT
}

\author{
Oleh \\ Romasi Lumban Gaol
}

\begin{abstract}
ABSTRAK
Tujuan penelitian ini adalah untuk mendapatkan bukti empiris tentang pengaruh kompetensi, independensi dan integritas auditor terhadap kualitas audit pada Kantor Akuntan Publik di Kota Medan. Populasi penelitian adalah seluruh Auditor Kantor Akuntan Publik di Kota Medan dengan jumlah Auditor sebanyak 70 orang sebagai sampel penelitian. Berdasarkan uji koefisien determinasi menunjukkan bahwa variabel kualitas audit dijelaskan oleh variabel kompetensi, independensi, dan integritas sebesar 72,2\%, sedangkan sisanya $27,8 \%$ dijelaskan oleh sebab lain di luar model. Hasil statistik dengan uji $\mathrm{F}$ diperoleh nilai F-hitung sebesar 30,381 dengan probabilitas 0,000. Karena probabilitas jauh lebih kecil dari nilai signifikan 0,05, maka model regresi dapat digunakan untuk memprediksi kualitas audit atau dapat dikatakan bahwa kompetensi, independensi, dan integritas auditor secara simultan berpengaruh terhadap kualitas audit. Hasil uji t menunjukkan bahwa variabel kompetensi berpengaruh positif signifikan terhadap kualitas audit, sehingga semakin baik tingkat kompetensi, maka akan semakin baik kualitas audit yang dilakukannya. Variabeli Independensi berpengaruh secara positif signifikan terhadap kualitas audit, sehingga semakin independen seorang auditor, maka akan semakin baik kualitas audit yang dilakukannya. Variabel integritas berpengaruh positif terhadap kualitas audit, sehingga semakin baik tingkat integritas, maka akan semakin baik kualitas audit yang dilakukannya.
\end{abstract}

Kata Kunci : Kompetensi, Independensi dan Integritas dan kualitas audit

\section{PENDAHULUAN}

Untuk mencapai kulitas audit yang tinggi seorang auditor harus mematuhi kode etik profesi yang mengatur perilaku akuntan publik dalam menjalankan praktik profesinya baik dengan sesama anggota maupun dengan masyarakat umum. Dalam Kode etik profesi menekankan sekali pentingnya independensi karena independensi merupakan dasar dari prinsip objektifitas dan integritas. Arens (2011) menyatakan bahwa independensi dalam audit berarti mengambil sudut pandang yang tidak bisa memihak dalam melakukan pengujian audit. Independensi ini sangat penting karena alasan banyaknya pengguna laporan keuangan mengandalkan laporan audit eksternal terhadap kewajaran laporan keuangan eksternal.

Masyarakat sebagai pengguna jasa profesi membutuhkan; pertama, akuntan professional, label profesional disini mengisyaratkan suatu 
kebanggaan, komitmen pada kualitas, dedikasi pada kepentingan klien dan keinginan tulus dalam membantu permasalahan yang dihadapi klien sehingga profesi tersebut dapat menjadi kepercayaan masyarakat; kedua kompetensi, yaitu sebagai aspek-aspek pribadi dari seorang pekerja yang memungkinkan dia untuk mencapai kinerja superior. Aspek-aspek pribadi ini mencakup sifat, motif-motif, nilai, sikap, pengetahuan dan ketrampilan dimana kompetensi akan mengarahkan tingkah laku, sedangkan tingkah laku akan menghasilkan kinerja.

Kompetensi juga merupakan pengetahuan, ketrampilan, dan kemampuan yang berhubungan dengan pekerjaan, serta kemampuan yang dibutuhkan untuk pekerjaan-pekerjaan non-rutin. Definisi kompetensi dalam bidang auditing pun sering diukur dengan pengalaman; ketiga independensi, berarti sikap mental yang bebas dari pengaruh, tidak dikendalikan oleh orang lain, tidak tergantung pada orang lain. Independensi dapat juga diartikan adanya kejujuran dalam diri auditor dalam mempertimbangkan fakta dan adanya pertimbangan yang obyektif tidak memihak dalam diri auditor dalam merumuskan dan menyatakan pendapatnya.

Menurut Indranata (2006), kompetensi adalah keseluruhan pengetahuan, kemampuan/keterampilan dan sikap kerja ditambah atribut kepribadian yang dimiliki oleh seseorang yang mencakup kemampuan berfikir kreatif, keluasan pengetahuan, kecerdasan emosional, pengalaman, daya juang, sikap positif, keterampilan kerja serta kondisi kesehatan yang baik yang bias dibuktikan atau diperagakan dalam melaksanakan tugas dan tanggung jawab yang dibebankan kepadanya. Christiawan (2002) dan Alim dkk. (2007) menyatakan bahwa semakin tinggi kompetensi auditor maka kualitas hasil pemeriksaan dan kinerja pemeriksa akan meningkat.

Selain kompetensi, integritas juga mempengaruhi kinerja auditor. Menurut Mulyadi (2002), integritas adalah suatu elemen karakter yang mendasari timbulnya pengakuan profesional. Integritas merupakan kualitas yang melandasi kepercayaan publik dan merupakan patokan (benchmark) bagi anggota dalam menguji semua keputusan yang diambilnya. Sunarto (2003) menyatakan bahwa integritas dapat menerima kesalahan yang tidak disengaja dan perbedaan pendapat yang jujur, tetapi tidak dapat menerima kecurangan prinsip. Dengan integritas yang tinggi, maka auditor dapat meningkatkan kualitas auditor.

Seorang auditor yang independen adalah mereka yang dapat bekerja bebas tanpa benturan dan tekanan apapun dan dari manapun, dan objektif. Penelitian mengenai independensi auditor pernah dilakukan 
sebelumnya oleh Rapina dkk (2010) yang menyimpulkan bahwa independensi auditor berpengaruh positif dan signifikan terhadap kualitas hasil audit.

Penelitian ini penting dilakukan mengingat pentingnya hasil audit yang berkualitas, karena dengan hasil audit yang berkualitas akan dihasilkan laporan keuangan yang andal dan dapat dipercaya sebagai dasar pengambilan keputusan. Semakin meningkatnya kualitas audit yang dihasilkan, maka akan meningkatkan kepercayaan masyarakat terhadap auditor.

Mencermati permasalahan diatas, perlu kiranya menguji pengaruh kompetensi, independensi dan integritas akuntan terhadap kulalitas audit. Masalah yang diteliti selanjutnya dapat dirumuskan dalam pertanyaan sebagai berikut: Apakah kompetensi, independensi dan integritas akuntan berpengaruh terhadap kualitas audit.

\section{TELAAH TEORI}

\section{Kualitas Audit}

Kualitas audit dapat diartikan sebagai bagus tidaknya suatu pemeriksaan yang telah dilakukan oleh auditor. Berdasarkan Standar Profesional Akuntan Publik (SPAP) audit yang dilaksanakan auditor dikatakan berkualitas, jika memenuhi ketentuan atau standar pengauditan. Standar pengauditan mencakup mutu professional, auditor independen, pertimbangan (judgement) yang digunakan dalam pelaksanaan audit dan penyusunan laporan audit.

De Angelo (1981) dalam Kusharyanti (2003) mendefinisikan kualitas audit sebagai kemungkinan (probability) dimana auditor akan menemukan dan melaporkan pelanggaran yang ada dalam sistem akuntansi klien. Adapun kemampuan untuk menemukan salah saji yang material dalam laporan keuangan perusahaan tergantung dari kompetensi auditor sedangkan kemauan untuk melaporkan temuan salah saji tersebut tergantung pada independensinya.

Dari pengertian tentang kualitas audit di atas maka dapat disimpulkan bahwa kualitas audit merupakan segala kemungkinan (probability) dimana auditor pada saat mengaudit laporan keuangan klien dapat menemukan pelanggaran yang terjadi dalam sistem akuntansi klien dan melaporkannya dalam laporan keuangan auditan, dimana dalam melaksanakan tugasnya tersebut auditor berpedoman pada standar auditing dan kode etik akuntan publik yang relevan. 


\section{Kompetensi}

Menurut Arens (2011) kompetensi adalah kualitas pribadi yang harus dimiliki oleh seorang auditor yang diperoleh melalui latar belakang pendidikan formal auditing dan akuntansi, pelatihan kerja yang cukup dalam profesi dan akan ditekuninya dan selalu mengikuti pendidikanpendidikan profesi yang berkelanjutan.

Nizarul dkk, (2007) mendefenisikan tentang kompetensi yang sering dipakai adalah karkteristik - karakteristik yang mendasari individu dalam mencapai kinerja superior. Menurut Sukrisno (2004), kompetensi adalah suatu pencapaian dan pemeliharaan suatu tingkat pengertian dan pengetahuan yang dapat memungkinkan anggota memberikan pelayanan dengan cakap dan baik.

Dari beberapa pendapat para ahli diatas dapat disimpulkan bahwa kompetensi adalah kualitas pribadi yang harus dimiliki seorang auditor yang dinilai dari latar belakang pendidikan, pelatihan kerja yang cukup, kemampuan berfikir kreatif, keluasan pengetahuan, kecerdasan emosional yang baik, keterampilan kerja yang memadai serta daya juang yang tinggi. Sehingga memungkinkan auditor tersebut mampu memberikan pelayanan jasa professional yang kompeten serta diiringi dengan hasil kerja yang berkualitas.

\section{Independensi}

Definisi independensi dalam The CPA Handbook menurut E.B. Wilcox adalah merupakan suatu standar auditing yang penting karena opini akuntan independen bertujuan untuk menambah kredibilitas laporan keuangan yang disajikan oleh manajemen. Jika akuntan tersebut tidak independen terhadap kliennya, maka opininya tidak akan memberikan tambahan apapun (Mautz dan Sharaf, 1993). Kode Etik Akuntan tahun 1994 menyebutkan bahwa independensi adalah sikap yang diharapkan dari seorang akuntan publik untuk tidak mempunyai kepentingan pribadi dalam pelaksanaan tugasnya, yang bertentangan dengan prinsip integritas dan obyektivitas.

Menurut Messier et al (2005), independensi merupakan suatu istilah yang sering digunakan oleh profesi auditor. Independensi menghindarkan hubungan yang mungkin mengganggu obyektivitas auditor

Auditor dikatakan independen apabila dapat secara bebas melakukan pekerjaan pemeriksaannya. Dengan independensi, auditor dapat pertimbangan-pertimbangan yang tidak bisa dan tidak memihak sehingga pelaksanaan pekerjaannya menjadi layak. Internal auditor harus 
independen terhadap aktivitas bagian-bagian yang diperiksanya pada perusahaan.

\section{Integritas}

Menurut Arens (2011), integritas berarti bahwa seseorang bertindak sesuai dengan kata hatinya, dalam situasi seperti apapun. Sedangkan menurut Mulyadi (2002), integritas adalah suatu karakter yang menunjukan kemampuan seseorang untuk mewujudkan apa yang telah disanggupinya dan diyakini kebenarannya ke dalam kenyataan. Auditor yang berintegritas adalah auditor yang memiliki kemampuan untuk mewujudkan apa yang telah diyakini kebenarannya tersebut ke dalam kenyataan. Menurut Sukrisno (2004), integritas adalah unsur karakter yang mendasar bagi pengakuan profesional. Integritas merupakan kualitas dalam menguji semua keputusannya.

Menurut Prinsip Etika Profesi Akuntan Indonesia dalam Mulyadi (2002), untuk memelihara dan meningkatkan kepercayaan publik, setiap auditor harus memenuhi tanggung jawab profesionalnya dengan integritas setinggi mungkin. Integritas adalah suatu elemen karakter yang mendasari timbulnya pengakuan profesional. Integritas merupakan kualitas yang mendasari kepercayaan publik dan merupakan patokan (benchmark) bagi auditor dalam menguji semua keputusan yang diambilnya. Integritas mengharuskan seorang auditor untuk bersikap jujur dan transparan, berani, bijaksana dan bertanggung jawab dalam melaksanakan audit.

\section{Pengaruh Kompetensi Auditor terhadap Kualitas Audit}

Kompetensi auditor adalah auditor yang dengan pengetahuan dan pengalamannya yang cukup dan eksplisit dapat melakukan audit secara objektif, cermat dan seksama. Kompetensi yang dibutuhkan dalam melakukan audit yaitu pengetahuan dan kemampuan. Auditor harus memiliki pengetahuan untuk memahami entitas yang diaudit, kemudian auditor harus memiliki kemampuan untuk bekerja sama dalam tim serta kemampuan dalam menganalisa permasalahan. Christiawan (2002) dan Alim dkk. (2007) menyatakan bahwa semakin tinggi kompetensi auditor akan semakin baik kualitas hasil pemeriksaannya

Auditor harus selalu meningkatkan pengetahuan tentang audit dan ilmu pendukungnya. Auditor yang mempunyai keahlian dalam melaksanakan pemeriksaan akan dianggap mempunyai kompetensi yang tinggi. Auditor yang berpengalaman dalam penugasan profesional audit akan dianggap mempunyai kompetensi yang tinggi. Semakin tinggi kompetensi auditor maka kualitas audit yang dihasilkan akan semakin baik. 
Penelitian yang dilakukan Alim et.al (2007), Sukriah et.al (2009), Ilmiyati dan Suhardjo (2012) menemukan bukti empiris bahwa kompetensi berpengaruh signifikan terhadap kualitas audit. Hasil ini konsisten dengan penelitian De Angelo (1981) dan Tjun-tjun (2012).

Christiawan (2002) dan Alim et.al (2007) menyatakan bahwa semakin tinggi kompetensi auditor akan semakin baik kualitas hasil pemeriksaannya, tapi sebaliknya jika semakin rendah kompetensi auditor maka rendah pula kualitas hasil pemeriksaannya.

\section{Pengaruh Independensi Auditor terhadap Kualitas Audit.}

Independensi merupakan sikap yang diharapkan dari seorang akuntan publik untuk tidak mempunyai kepentingan pribadi dalam melaksanakan tugasnya, yang bertentangan dengan prinsip integritas dan objektivitas.

Auditor tidak boleh memihak kepada siapapun. Auditor harus dapat mepertahankan sikap mental dan penampilan karena opini yang dikeluarkannya untuk menambah kualitas hasil laporan pemeriksaan, sehingga jika auditor tersebut independen maka kualitas audit yang dihasilkan akan semakin baik.

Oleh karena itu cukuplah beralasan bahwa untuk menghasilkan audit yang berkualitas diperlukan sikap independen dari auditor. Karena jika auditor kehilangan independensinya maka laporan audit yang dihasilkan tidak sesuai dengan kenyataan yang ada sehingga tidak dapat digunakan sebagai dasar pengambilan keputusan.

Hasil penelitian Trisnaningsih (2007) mengindikasikan bahwa auditor yang hanya memahami good governance tetapi dalam pelaksanaan pemeriksaan tidak menegakkan independensinya maka tidak akan berpengaruh terhadap kinerjanya. Penelitian yang dilakukan Alim et.al (2007), Singgih dan Bawono (2010), Saripudin et.al (2012) menemukan bukti empiris independensi berpengaruh signifikan terhadap kualitas audit. Hasil ini konsisten dengan penelitian Suseno (2013) menyatakan untuk meningkatkan kualitas audit dapat diambil dengan cara mengembangkan sikap independensinya.

\section{Pengaruh Integritas Auditor terhadap Kualitas Audit.}

Integritas adalah suatu elemen karakter yang mendasari timbulnya pengakuan professional. Integritas mengharuskan seorang anggota untuk, antara lain, bersikap jujur dan berterus terang tanpa harus mengorbankan rahasia penerima jasa, pelayanan dan kepercayaan publik tidak boleh dikalahkan oleh keuntungan pribadi (Mulyadi, 2002). 
Kode Etik Akuntan Indonesia pasal 1 ayat dua menyatakan bahwa setiap auditor harus mempertahankan integritas, objektivitas dan independensi dalam melaksanakan tugasnya. Seorang auditor yang mempertahankan integritas akan bertindak jujur dan tegas dalam memertimbangkan fakta, terlepas dari kepentingan pribadi. Dalam hal ini auditor dituntut untuk bertindak jujur dan tegas dalam mengungkapkan semua bukti audit yang sesuai dengan keadaan yang sebenarnya tanpa dipengaruhi oleh pihak-pihak yang dapat menganggu integritas pribadi auditor. Sehingga kualitas pekerjaan auditor dapat dipercaya oleh publik sesuai dengan tatanan nilai tertinggi bagi anggota profesi, karena pada dasarnya integritas menjadi salah satu jaminan kualitas dalam menilai hasil kerja auditor.

Sunarto (2003) menyatakan bahwa integritas dapat menerima kesalahan yang tidak disengaja dan perbedaan pendapat yang jujur, tetapi tidak dapat menerima kecurangan prinsip. Dengan integritas yang tinggi maka kualitas hasil kerja auditor semakin baik.

Penelitian sebelumnya yang dilakukan Carolita dan Rahardjo (2012) menyatakan bahwa integritas berpengaruh positif terhadap kualitas audit, sehingga semakin tinggi integritas seorang auditor maka semakin baik kualitas audit yang dilakukannya

\section{Perumusan Hipotesis}

Berdasarkan telaah teoritis, hasil-hasil penelitian, serta kerangka pemikiran teoritis pengaruh antara kompetensi, independensi dan integritas terhadap kualitas audit, maka diajukan hipotesa sebagai berikut :

H 1 : Kompetensi mempunyai pengaruh terhadap kualitas audit.

H 2: Independensi mempunyai pengaruh terhadap kualitas audit.

H 3 : Integritas mempunyai pengaruh terhadap kualitas audit.

\section{METODE PENELITIAN}

\section{Populasi dan Teknik Pengambilan Sampel}

Rerangka sample penelitian ini menggunakan directory Ikatan Akuntan Indonesia kompartemen akuntan publik yang menginformasikan sebanyak 10 kantor akuntan publik (KAP) yang berdomisili / beroperasi di Kodya Medan. Unit analisis yang digunakan adalah individual, yaitu para staff yang bekerja pada kantor akuntan publik (KAP) yang berdomisili / beroperasi di Kodya Medan. 


\section{Definisi Operasional dan Pengukuran Variabel}

Dalam penelitian ini digunakan kuesioner tertutup yang diukur dengan 5 alternatif jawaban skala likert. Semua item pertanyaan diukur dengan skala likert 1-5, untuk mengukur sikap yang menyatakan setuju atau ketidak setuju terhadap pertanyaan yang diajukan dengan skor 5 SS (sangat setuju), $4 \mathrm{~S}$ (setuju), $3 \mathrm{R}$ (ragu-ragu), $2 \mathrm{TS}$ (tidak setuju), dan 1 STS (sangat tidak setuju).

\section{a. Kompetensi}

Kompetensi dalam pengauditan merupakan pengetahuan, keahlian, dan pengalaman yang dibutuhkan auditor untuk dapat melakukan audit secara objektif,cermat dan seksama. Kompetensi auditor diukur dengan menggunakan duabelas item pernyataan yang menggambarkan tingkat persepsi auditor terhadap bagaimana kompetensi yang dimilikinya terkait Mutu personal, Pengetahuan umum serta Keahlian khusus. Instrumen yang digunakan untuk mengukur kompetensi ini diadopsi dari penelitian Harhinto (2004).

\section{b. Independensi auditor}

Independensi dalam pengauditan merupakan penggunaan cara pandang yang tidak bias dalam pelaksanaan pengujian audit, evaluasi hasil pengujian tersebut, dan pelaporan hasil temuan audit. Independensi auditor diukur dengan menggunakan tujuh item pernyataan yang menggambarkan tingkat persepsi auditor terhadap Hubungan Dengan Klien, Independensi Pelaksanaan Pekerjaan, serta Independensi Laporan. Instrumen yang digunakan untuk mengukur independensi ini diadopsi dari penelitian Harhinto (2004)

\section{c. Integritas auditor}

Integritas merupakan sikap jujur,berani,bijaksana dan tanggung jawab auditor dalam melaksanakan audit. Alat ukur yang digunakan untuk mengukur integritas adalah sikap jujur, berani, bijaksana dan tanggungjawab auditor dalam melaksanakan audit (sukriah, 2009)

\section{d. Kualitas audit}

Kualitas audit didefinisikan sebagai kemungkinan seorang audior dapat menemukan dan melaporkan tentang adanya suatu pelanggaran dalam sistem akuntansi klienya (De Angelo, 1981). Audit yang dilakukan auditor dikatakan berkualitas, jika memenuhi standar audit dan pengendalian mutu. Indikator yang digunakan untuk mengukur kualitas audit adalah kesesuaian pemerikaan dengan standar audit, kualitas proses 
audit, kualitas laporan hasil pelaksanaan audit dan tindak lanjut hasil audit. Instrumen yang digunakan untuk mengukur kualitas audit diadopsi dari penelitian Sukriah (2009).

\section{Model Analisis Data}

Model analisis data yang digunakan pada penelitian ini adalah analisis regresi linier berganda (Multiple Linear Regression Analysis). Persamaan regresi linier berganda adalah sebagai berikut :

$\mathrm{Y}=\alpha+\beta 1 \mathrm{X} 1+\beta 2 \mathrm{X} 2+\beta 3 \mathrm{X} 3+\mathrm{e}$

Keterangan :

Y: Kualitas Audit.

X1 : Kompetensi Auditor.

$\mathrm{X} 2$ : Independensi Auditor.

$\mathrm{X} 3$ : Integritas Auditor.

$\alpha$ : Konstanta.

$\beta$ : Koefisien Regresi.

e : Error.

\section{Teknik Analisis Data}

\section{a. Uji Kualitas Data}

Komitmen pengukuran dan pengujian suatu kuesioner atau hipotesis sangat bergantung pada kualitas data yang dipakai dalam pengujian tersebut. Data penelitian tidak akan berguna jika instrumen yang digunakan untuk mengumpulkan data penelitian tidak memiliki reability (tingkat keandalan) dan validity (tingkat kebenaran/keabsahan yang tinggi).

\section{b. Uji Asumsi Klasik}

Untuk memperoleh hasil/nilai yang tidak bias atau estimator linear tidak bias yang terbaik (Best Linear Unbiased Estimator/ BLUE), maka model regresi harus memenuhi beberapa asumsi yang disebut dengan asumsi klasik. Asumsi klasik tersebut, yaitu:

\section{c. Uji Hipotesis}

Uji hipotesis dalam penelitian ini akan diuji dengan menggunakan analisis regresi linear yaitu analisis yang digunakan untuk mengetahui sejauh mana pengaruh

Kompetensi, indepensi dan integritas auditor sebagai variabel independen terhadap kualitas audit sebagai variabel dependen. untuk menguji hipotesis mengenai kompetensi, indepensi dan integritas auditor secara simultan dan 
parsial berpengaruh signifikan terhadap kualitas audit, digunakan pengujian hipotesis secara simultan dan secara parsial.

\section{HASIL DAN PEMBAHASAN}

\section{Statistik Diskriptif}

Untuk memberikan gambaran mengenai variabel-variabel penelitian (Kompetensi, Independensi dan Integritias, serta Kualitas Audit) digunakan tabel statistik deskriptif yang menunjukkan angka minimum, maxsimum, mean dan standar deviasi yang dapat dilihat dalam tabel 1

TABEL 1

STATISTIK DESKRIPTIF VARIABEL PENELITIAN

\begin{tabular}{|l|c|c|c|c|c|}
\hline \multicolumn{1}{|c|}{ Variabel } & N & Minimum & Maxsimum & Mean & $\begin{array}{c}\text { Standar } \\
\text { Deviasi }\end{array}$ \\
\hline Kualitas Audit & 70 & 26 & 45 & 37,93 & 3.474 \\
Kompetensi & 70 & 32 & 44 & 38,94 & 2.745 \\
Independensi & 70 & 29 & 40 & 37,51 & 2.749 \\
Integritias & 70 & 32 & 45 & 39,91 & 2.832 \\
& & & & & \\
\hline
\end{tabular}

\section{Sumber : Data Primer diolah 2016}

Dari Tabel 1 di atas diketahui bahwa jumlah sampel yang digunakan dalam penelitian ini sebanyak 70 orang auditor. Untuk variabel kompetensi tersebut diketahui memiliki nilai rata-rata sebesar 38,94 dengan deviasi standar 2,745, nilai tertinggi 44,00 dan nilai terendah 32,00. Untuk variabel Independensi memiliki nilai rata-rata sebesar 37,51 dengan deviasi standar 2,749, nilai tertinggi 40,00 dan nilai terendah 29,00. Untuk variabel integritas memiliki nilai rata-rata sebesar 39,91 dengan deviasi standar 2,832, nilai tertinggi sebesar 45,00 dan terendah sebesar 32,00. Sedangkan untuk variabel kualitas audit memiliki nilai rata-rata sebesar 37,93 dengan deviasi standar 3,474, nilai tertinggi sebesar 45,00 dan terendah sebesar 26,00.

\section{Uji Reliabilitas}

Hasil pengujian dengan menggunakan program SPSS menunjukkan bahwa nilai cronbach alpha instrumen variabel Kompetensi sebesar 0,861 
dan instrumen variabel Independensi sebesar 0,775 sedangkan instrumen variabel Integritas sebesar 0,862 serta instrumen variabel Kualitas Audit sebesar 0,819. Artinya instrumen variabel Kompetensi, instrumen variabel Independensi, instrumen variabel Integritas serta instrumen variabel Kualitas Audit adalah handal atau reliabel untuk digunakan dalam pengolahan data.

\section{Uji Validitas}

Uji validitas digunakan untuk mengukur sah atau valid tidaknya suatu kuesioner. Suatu kuesioner dikatakan valid jika pertanyaan pada kuesioner mampu untuk mengungkapkan sesuatu yang akan diukur oleh kuesioner tersebut. Dalam penelitian ini untuk mengukur validitas digunakan Coeficient correlation pearson yaitu dengan menghitung korelasi antara score masing-masing butir pertanyaan dengan total score, Imam Ghozali (2013). Variabel Kompetensi auditor terdiri atas 12 item pernyataan. Variabel independensi auditor terdiri atas 7 item pernyataan. Variabel integritas auditor terdiri atas 14 item pernyataan dan variabel kualitas audit terdiri atas 12 pernyataan. Hasil pengujian dengan menggunakan program SPSS menunjukkan nilai pearson instrumen kompetensi auditor dinyatakan valid karena nilai korelasi yang dihasilkan pada korelasi diatas 0,3 (Aswar, 2000). Nilai pearson instrumen independensi auditor dinyatakan valid karena nilai korelasi yang dihasilkan pada korelasi diatas 0,3 (Aswar, 2000). Nilai pearson instrumen integritas auditor dinyatakan valid karena nilai korelasi yang dihasilkan pada korelasi diatas 0,3 (Aswar, 2000). Nilai pearson instrumen kualitas audit dinyatakan valid karena nilai korelasi yang dihasilkan pada korelasi diatas 0,3 (Aswar, 2000). Jadi dapat disimpulkan bahwa masing-masing butir pernyataan adalah valid. Sehingga data yang dikumpulkan dalam instrumen penelitian ini layak untuk dianalisa lebih lanjut.

\section{Normalitas}

Uji normalitas data dalam penelitian ini menggunakan Uji Kolmologorov-Smirnov (Uji K-S) dengan ringkasan hasil analisis sebagaimana disajikan pada tabel 2 berikut ini: 
TABEL 2

HASIL UJI NORMALITAS

One-Sample Kolmogorov-Smirnov Test

\begin{tabular}{|ll|r|}
\hline & & \multicolumn{1}{|c|}{ Unstandardized } \\
\hline $\mathrm{N}$ & Residual \\
Normal Parameters $^{\mathrm{a}}$ & Mean & 70 \\
& Std. Deviation & .0000000 \\
Most Extreme Differences & Absolute & 1.91907811 \\
& Positive & .123 \\
& Negative & .123 \\
Kolmogorov-Smirnov Z & & -.091 \\
Asymp. Sig. (2-tailed) & & 1.026 \\
\hline
\end{tabular}

a. Test distribution is Normal.

Sumber: Data primer diolah, 2016

Hasil uji normalitas pada Tabel 2 di atas didapatkan nilai K-S sebesar 1,026 dengan signifikan 0,243 (karena nilai $\mathrm{P}=0,243$, lebih besar dari 0,05). Hal tersebut memberikan gambaran bahwa sebaran data tidak menunjukkan penyimpangan dari kurva normalnya, yang berarti bahwa sebaran data telah memenuhi asumsi normalitas.

\section{Multikolinearitas}

Untuk menguji adanya multikolinearitas dapat dilihat melalui nilai Variance Inflantion Factor (VIF) $<10$ dan tolerance $>0,1$. Variabel X1 dengan nilai VIF 1,683, variabel X2 dengan nilai VIF 1,165, variabel X3 dengan nilai VIF 1,842 adalah nilai VIF yang kecil dari 10 , dan nilai tolerance adalah $>$ dari 0,1 yaitu 0,594 untuk variabel $\mathrm{X}_{1}, 0,858$ untuk variabel $\mathrm{X}_{2}, 0,543$ untuk variabel X3 . Dengan demikian dapat dikatakan bahwa tidak terdapat korelasi variabel-variabel bebas antara satu dengan yang lainnya. Dapat dilihat pada tabel 3 berikut: 
TABEL 3

HASIL UJI MULTIKOLINEARITAS

Coefficients $^{\text {a }}$

\begin{tabular}{|c|c|c|c|c|c|c|c|c|}
\hline & \multirow[b]{2}{*}{ Model } & \multicolumn{2}{|c|}{$\begin{array}{c}\text { Unstandardized } \\
\text { Coefficients }\end{array}$} & \multirow{2}{*}{\begin{tabular}{|c}
$\begin{array}{c}\text { Standardized } \\
\text { Coefficients }\end{array}$ \\
Beta \\
\end{tabular}} & \multirow[b]{2}{*}{$\mathrm{T}$} & \multirow[b]{2}{*}{$\mathrm{Sig}$} & \multicolumn{2}{|c|}{$\begin{array}{c}\text { Collinearity } \\
\text { Statistics }\end{array}$} \\
\hline & & $\mathrm{B}$ & Std. Error & & & & Toleranc & VIF \\
\hline \multirow[t]{4}{*}{1} & (Constant) & - & 4.261 & & - & .010 & & \\
\hline & Kompetensi & .634 & .112 & .501 & 5.678 & .000 & .594 & 1.68 \\
\hline & Independen & .214 & .093 & .169 & 2.305 & .024 & .858 & 1.16 \\
\hline & Integritas & .415 & .113 & .338 & 3.668 & .000 & .543 & 1.84 \\
\hline
\end{tabular}

a. Dependent Variable: Kualitas aUDIT

Sumber: Data primer yang diolah, 2016

\section{Heterokedastisitas}

Berdasarkan Tabel 4, dapat dilihat tidak ada variable yang signifikan dalam regresi dengan variabel Absut. Tingkat signifikansi $>\alpha=$ 0,05, sehingga dapat disimpulkan bahwa model yang digunakan dalam penelitian ini terbebas dari heterokedastisitas.

\section{TABEL 4 \\ HASIL UJI HETEROKEDASTISITAS}

\section{Coefficients $^{\text {a }}$}

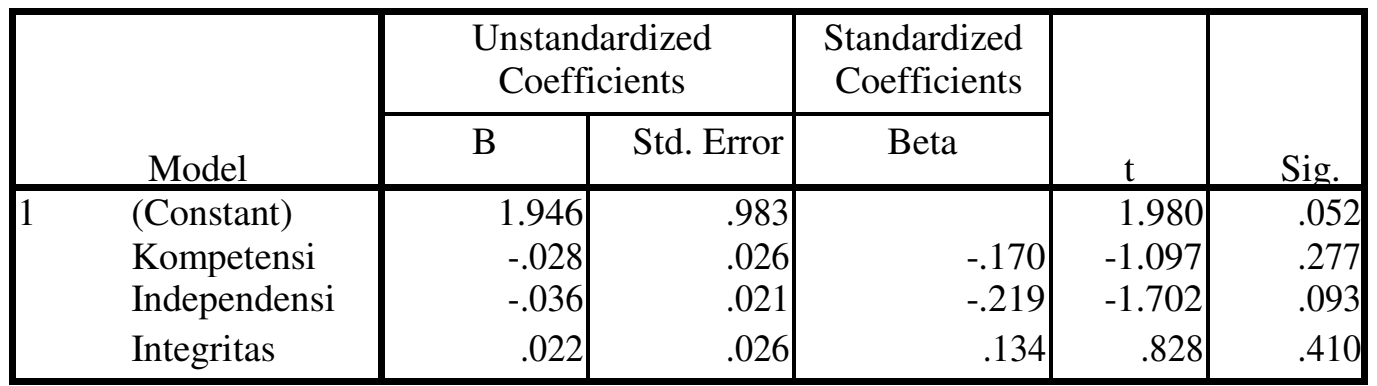

a. Dependent Variable: ABSUT

Sumber: Data primer diolah, 2016

\section{Analisa Regresi Linear Berganda}

Analisa regresi linear berganda digunakan untuk mencari hubungan atau pengaruh antara variabel independent (kompetensi auditor, independensi auditor, integritas auditor) terhadap variabel dependent 
(kualitas audit). Hasil analisa regresi linier berganda dapat dilihat pada tabel 5.

TABEL 5

HASIL UJI REGRESI LINEAR BERGANDA

Coefficients(a)

\begin{tabular}{|cl|c|l|l|c|c|}
\hline \multirow{2}{*}{ Model } & \multicolumn{2}{|c|}{$\begin{array}{c}\text { Unstandardized } \\
\text { Coefficients }\end{array}$} & $\begin{array}{c}\text { Standardized } \\
\text { Coefficients }\end{array}$ & \multirow{2}{*}{$\mathrm{t}$} & \multirow{2}{*}{ Sig } \\
\hline & & B & Std. & Bet & & \\
\hline 1 & (Constant) & 3,187 & 3,113 & & 1,024 & 0,314 \\
& KOMPETENSI & 0,294 & 0,135 & 0,304 & 2,183 & 0,037 \\
& INDEPENDEN & 0,326 & 0,143 & 0,285 & 1,587 & 0,023 \\
& INTEGRITAS & 0,481 & 0,148 & 0,479 & 3,259 & 0,003 \\
\hline
\end{tabular}

Sumber: Data primer diolah, 2016

Persamaan regresi linear berganda dalam penelitian ini berdasarkan tabel 5 tersebut adalah sebagai berikut:

$\mathrm{Y}=3,187+0,294 \mathrm{X}_{1}+0,326 \mathrm{X}_{2}+0,481 \mathrm{X}_{3}$

dimana:

$\mathrm{Y} \quad=$ Kualitas Audit struktur modal

$\mathrm{X}_{1} \quad=$ Kompetensi Auditor

$\mathrm{X}_{2} \quad=$ Independensi Auditor

$\mathrm{X}_{3} \quad=$ Integritas Auditor

\section{Koefisien Determinasi Hipotesis}

Berdasarkan tampilan output model summary pada tabel 6 , besarnya adjusted $\mathrm{R}^{2}$ (koefisien determinasi yang telah disesuaikan) adalah 0,722 . Nilai ini menunjukkan bahwa $72,2 \%$ variasi kualitas audit dapat dijelaskan oleh variasi dari ketiga variabel yaitu kompetensi, independensi, dan integritas, sedangkan sisanya $27,8 \%$ dijelaskan oleh sebab lain di luar model.

Standard Error of Estimate (SEE) 1,971 apabila dibandingkan dengan standard deviation variabel dependen kualitas audit 3,736 adalah lebih kecil. Hal ini mengindikasikan variabel-variabel independen lebih baik dalam memprediksi variasi dependen kualitas audit daripada rata-rata kualitas audit itu sendiri. 
TABEL 6

HASIL UJI KOEFISIEN DETERMINASI

Model Summary(b)

\begin{tabular}{|l|c|c|c|c|l|}
\hline Model & $\mathrm{R}$ & $\mathrm{R}$ & $\begin{array}{c}\text { Adjusted } \mathrm{R} \\
\text { Square }\end{array}$ & $\begin{array}{c}\text { Std. Error of } \\
\text { the Estimate }\end{array}$ & Durbin-Watson \\
\hline 1 & $0,864(\mathrm{a})$ & 0,74 & 0,722 & 1,971 & 1,686 \\
\hline
\end{tabular}

Sumber: Data primer diolah, 2016

\section{Pengujian Hipotesis Secara Simultan (Uji F)}

Dari hasil pengujian terhadap uji simultan ANOVA atau F test seperti yang ditampilkan pada tabel 7 di bawah ini diperoleh nilai Fhitung sebesar 30,381 dengan probabilitas 0,000. Karena probabilitas jauh lebih kecil dari nilai signifikan 0,05, maka model regresi dapat digunakan untuk memprediksi kualitas audit atau dapat dikatakan bahwa kompetensi, independensi, dan integritas auditor secara simultan berpengaruh terhadap kualitas audit.

TABEL 7

HASIL UJI SIMULTAN (UJI F)

$\operatorname{ANOVA}(\mathbf{b})$

\begin{tabular}{|c|c|c|c|c|c|c|}
\hline Model & & Sum of Squares & Df & $\begin{array}{l}\text { Mean } \\
\text { Square }\end{array}$ & $\mathrm{F}$ & Sig. \\
\hline 1 & $\begin{array}{l}\text { Regression } \\
\text { Residual } \\
\text { Total }\end{array}$ & $\begin{array}{l}354,209 \\
120,476 \\
474,686\end{array}$ & $\begin{array}{c}3 \\
31 \\
34\end{array}$ & $\begin{array}{c}118,070 \\
3,886\end{array}$ & 30,381 & 0,000 (a) \\
\hline
\end{tabular}

Sumber: Data primer diolah, 2016

Secara lebih tepat, nilai Fhitung dibandingkan dengan Ftabel dimana jika Fhitung $>$ Ftabel maka secara simultan variabel-variabel independen berpengaruh signifikan terhadap variabel dependen. Pada taraf $\alpha=0,05$ dengan derajat kebebasan pembilang/df1 $(\mathrm{k})=3$ (jumlah variabel independen) dan derajat kebebasan penyebut/df2 (n-k-1) $=31$, diperoleh nilai Ftabel 2,911. Dengan demikian, nilai Fhitung 30,381 lebih besar dari nilai Ftabel (2,911). Berdasarkan hasil perhitungan tersebut dapat diinterpretasikan bahwa variabel kompetensi, independensi, dan integritas secara bersama-sama mempengaruhi variabel kualitas audit. 


\section{Pengujian Hipotesis Secara Parsial (Uji t)}

Hasil pengujian hipotesis pertama (H1) yang menyebutkan bahwa kompetensi auditor berpengaruh positif terhadap kualitas audit dikonfirmasi pada table 8 . Tabel 8 tersebut menunjukkan bahwa nilai koefisien regresi variabel kompetensi auditor (X1) adalah 0,294 dan nilai thitung 2,183. Nilai koefisien regresi ini signifikan pada tingkat signifikansi 0,05 dengan $\mathrm{p}$ value sebesar 0,037 .

\section{TABEL 8.}

HASIL UJI PARSIAL (UJI t)

Coefficients(a)

\begin{tabular}{|cl|c|c|c|c|c|}
\hline \multirow{2}{*}{ Model } & \multicolumn{2}{|c|}{$\begin{array}{c}\text { Unstandardized } \\
\text { Coefficients }\end{array}$} & $\begin{array}{c}\text { Standardized } \\
\text { Coefficients }\end{array}$ & & \\
\cline { 1 - 3 } & & $\mathrm{B}$ & Std. Error & Beta & $\mathrm{t}$ & $\mathrm{Sig}$ \\
\hline 1 & (Constant) & 3,187 & 3,113 & & 1,024 & 0,314 \\
& KOMPETENSI & 0,294 & 0,135 & 0,304 & 2,183 & 0,037 \\
& INDEPENDENSI & 0,326 & 0,143 & 0,185 & 2,587 & 0,023 \\
& INTEGRITAS & 0,481 & 0,148 & 0,479 & 3,259 & 0,003 \\
\hline
\end{tabular}

Sumber: Data primer diolah, 2016

Hasil ini dipertegas dengan hasil perhitungan nilai thitung dan ttabel. Nilai ttabel pada taraf signifikansi 5\% dan df (derajat kebebasan) $\mathrm{n}-\mathrm{k}-1=31$ adalah 2,040. Dengan demikian, nilai thitung 2,183 $>$ ttabel 2,040. Hasil pengujian ini menginterpretasikan bahwa variabel kompetensi auditor berpengaruh positif dan signifikan terhadap kualitas audit pada taraf signifikansi 5\% atau dengan kata lain $\mathrm{H} 1$ diterima.

Hasil pengujian hipotesis kedua $(\mathrm{H} 2)$ yang menyebutkan bahwa independensi auditor berpengaruh positif terhadap kualitas audit dikonfirmasi pada table 5.15. Ditunjukkan bahwa nilai koefisien regresi variabel independensi auditor (X2) adalah 0,226 dan nilai thitung 2,587. Nilai koefisien regresi signifikan pada tingkat signifikansi 0,05 dengan $\mathrm{p}$ value sebesar 0,023 . Hasil ini menjelaskan bahwa nilai koefisien regresi variabel independensi auditor (X2) berpengaruh positif terhadap kualitas audit.

Hasil ini diperkuat dengan hasil perhitungan nilai thitung dan ttabel. Nilai ttabel pada taraf signifikansi 5\% dan df (derajat kebebasan) $\mathrm{n}-\mathrm{k}-1=31$ adalah 2,040. Dengan demikian, nilai thitung 2,587 $>$ tabel 
2,040 sehingga perubahan atau variasi variabel independensi diikuti oleh variasi kualitas audit. Berdasarkan hasil pengujian $\mathrm{H} 2$ ini dapat diinterpretasikan bahwa variabel independensi auditor berpengaruh signifikan terhadap kualitas audit pada taraf signifikansi 5\% atau dengan kata lain $\mathrm{H} 2$ diterima.

Hasil pengujian hipotesis ketiga (H3) yang menyebutkan bahwa integritas auditor berpengaruh positif terhadap kualitas audit dikonfirmasi pada table 5.15. Hasil pengujian tersebut menunjukkan bahwa nilai koefisien regresi variable integritas auditor (X3) adalah 0,481 dan nilai thitung 3,259. Nilai koefisien regresi ini signifikan pada tingkat signifikansi 0,05 dengan $\mathrm{p}$ value sebesar 0,003 .

Hasil ini didukung oleh hasil perhitungan nilai thitung dan ttabel. Nilai ttabel pada taraf signifikansi 5\% dan df (derajat kebebasan) n-k-1 = 31 adalah 2,040. Dengan demikian, nilai thitung 3,259 > tabel 2,040. Hasil pengujian ini menginterpretasikan bahwa variabel integritas auditor berpengaruh positif dan signifikan terhadap kualitas audit pada taraf signifikansi 5\% atau dengan kata lain $\mathrm{H} 3$ diterima.

\section{Pembahasan Hasil Penelitian}

\section{a. Pengaruh Kompetensi Auditor Terhadap Kualitas Audit}

Hasil penelitian menunjukan bahwa kompetensi audit berpengaruh signifikan positif terhadap kualitas auditor. Pengaruh antara kompetensi auditor searah dengan kualitas audit. Ini berarti bahwa hubungan antara kompetensi auditor searah dengan pelaksanaan kualitas auditor. Semakin kompeten seorang auditor akan semakin tinggi kualitas audit.

Hasil penelitian ini sejalan dengan teori oleh Tunggal (2008:10), standar auditing berkaitan dengan kriteria atau ukuran mutu kinerja. Dalam hal ini kompetensi auditor diatur dalam standar umum yang bersifat pribadi dan berkaitan dengan prasyarat auditor dan mutu pekerjaannya. Penelitian ini sejalan dengan penelitian yang dilakukan Yossi (2011) menyatakan bahwa Hasil pengujian kualitas audit yang dilakukan oleh auditor KAP minimal sebesar 9,472 dan kualitas audit tersebut akan terus meningkat sebesar 0,361 jika auditor meningkatkan kompetensinya. Dengan demikian dapat dikatakan bahwa kompetensi auditor berpengaruh secara signifikan terhadap kualitas audit oleh auditor KAP

Hasil pengujian hipotesis ini sejalan dengan pendapat De Angelo bahwa kemungkinan (probability) dimana auditor akan menemukan salah saji tergantung pada kualitas pemahaman auditor (kompetensi). Hasil penelitian ini sejalan pula dengan hasil penelitian 
yang dilakukan oleh Harhinto (2004) bahwa keahlian yang diproksikan dalam intensitas pengalaman dan tingkat pengetahuan auditor berhubungan positif terhadap kualitas audit. Hasil tersebut dapat dipahami bahwa untuk meningkatkan kualitas audit, seorang auditor sangat bergantung pada tingkat kompetensinya. Jika auditor memiliki kompetensi yang baik maka auditor akan dengan mudah melakukan tugas- tugas auditnya dan sebaliknya jika rendah maka dalam melaksanakan tugasnya, auditor akan mendapatkan kesulitan-kesulitan sehingga kualitas audit yang dihasilkan akan rendah pula.

Hasil penelitian ini juga didukung oleh data pendidikan responden sebagian besar adalah Strata 1 dan sudah memiliki pengalaman kerja lebih dari 3 tahun, ini akan memudahkan auditor dalam mendeteksi tingkat kecurangan yang ada, sehingga bisa meningkatkan kualitas hasil kerja auditor. Selain itu dilihat dari data distribusi frekuensi variabel kompetensi auditor yang salah satu indikatornya, memiliki pengetahuan mendapat penilaian baik. Auditor memiliki pengetahuan dan pengalaman memadai dalam bidang audit dengan mengikuti pendidikan umum dan pendidikan khusus untuk mencapai kompetensi profesional. Auditor yang kompeten dan berpengalaman akan menyelesaikan pekerjaan audit dengan lebih baik dari pada auditor yang tidak kompeten dan berpengalaman rendah.

\section{b. Pengaruh Independensi Auditor Terhadap Kualitas Audit}

Hipotesis kedua menyatakan bahwa independensi berpengaruh signifikan terhadap kualitas audit. Hasil penelitian menunjukan bahwa independensi auditor berpengaruh signifikan positif terhadap kualitas audit. Ini berarti bahwa hubungan antara objektivitas searah dengan pelaksanaan kualitas hasil kerja auditor. Semakin baik objektivitas seorang auditor akan semakin baik kualitas hasil kerja auditor.

Hasil penelitian ini sejalan dengan teori yang dinyatakan dalam pernyataan SPKN 2007, pernyataan standar umum kedua menyatakan bahwa "Dalam semua hal yang berkaitan dengan pekerjaan pemeriksaan, organisasi pemeriksa dan pemeriksa, harus bebas dalam sikap mental dan penampilan dari gangguan pribadi, ekstern, dan organisasi yang dapat mempengaruhi independensinya.

Hasil penelitian ini sejalan dengan penelitian Elfarini (2009) yang menyatakan bahwa independensi berpengaruh positif terhadap kualitas audit, dimana semakin independen seorang auditor maka semakin baik kualitas audit. Oleh karena itu ia tidak dibenarkan memihak kepada siapapun, sebab bagaimanapun sempurnanya keahlian teknis yang 
dimilikinya, ia akan kehilangan sikap tidak memihak yang justru sangat diperlukan untuk mempertahankan kebebasan pendapatnya.

Penelitian ini tidak sejalan dengan penelitian yang dilakukan oleh Sukriah dkk (2009), dengan nilai signifikan yang di peroleh sebesar 0,764 dengan koefisien regresi -0,013, yang menyatakan bahwa independensi auditor tidak signifikan terhadap kualitas audit yang disebabkan karena independensi aparat inspektorat masih terpengaruh dengan penentu kebijakan dan sering adanya mutasi antar satuan kerja perangkat daerah, serta ketidak signifikanan independensi terhadap kualitas audit disebabkan karena pada saat penyusunan program pemeriksaan masih ada intervensi pimpinan untuk menentukan, mengeliminasi atau memodifikasi bagianbagian tertentu yang akan diperiksa serta intervensi atas prosedurprosedur yang dipilih oleh auditor.

Independensi merupakan aspek yang penting bagi seorang auditor. Meskipun auditor memiliki kemampuan teknik yang cukup dalam bidang audit, tetapi profesi ini juga membutuhkan kepercayaan dari masyarakat. Independensi auditor merupakan dasar utama kepercayaan masyarakat terhadap auditor dan merupakan faktor yang sangat penting guna menilai kualitas hasil kerja auditor untuk diakui sebagai seorang yang independen.

\section{c. Pengaruh Integritas Auditor Terhadap Kualitas Audit}

Hasil penelitian menunjukan bahwa integritas auditor berpengaruh signifikan positif terhadap kualitas audit. Ini berarti bahwa hubungan antara integritas searah dengan pelaksanaan kualitas audit. Hal ini berarti bahwa semakin baik integritas seorang auditor akan semakin bagus kualitas audit yang dihasilkan auditor. Seorang auditor harus mampu menjaga integritasnya artinya auditor tersebut harus bersikap jujur dan transparan, berani, bijaksana dan bertanggung jawab dalam melaksanakan audit. Penelitian ini tidak sejalan dengan dengan penelitian yang dilakukan oleh ika sukriah dengan tingkat signifikan 0,701 dengan koefisien regresi $-0,027$ yang menyatakan integritas auditor tidak berpengaruh terhadap kualitas audit, yang disebabkan dengan kemungkinan adanya pernyataan-pernyataan sensitive yang dapat menimbulkan tidak kesignifikanan hasil.

Hasil penelitian ini sejalan dengan teori Mulyadi (2002:56), integritas adalah suatu karakter yang menunjukan kemampuan seseorang untuk mewujudkan apa yang telah disanggupinya dan diyakini kebenarannya ke dalam kenyataan. Auditor yang berintegritas adalah 
auditor yang memiliki kemampuan untuk mewujudkan apa yang telah diyakini kebenarannya tersebut ke dalam kenyataan.

Dengan mempertahankan integritas dalam bekerja sangat penting bagi penilaian kualitas hasil kerja atau kinerja auditor. Auditor yang berintegritas tinggi akan bertindak jujur dan tegas dalam mempertimbangkan fakta pada saat menyelesaikan pekerjaan audit.

\section{KESIMPULAN, KETERBATASAN DAN SARAN}

\section{Kesimpulan}

Berdasarkan hasil penelitian maka dapat diambil kesimpulan sebagai berikut :

1. Kompetensi, independensi, dan integritas secara simultan berpengaruh terhadap kualitas audit yang dilaksanakan oleh auditor Kota Medan.

2. Kompetensi berpengaruh positif signifikan terhadap kualitas audit, sehingga semakin baik tingkat kompetensi, maka akan semakin baik kualitas audit yang dilakukannya.

3. Independensi berpengaruh secara positif signifikan terhadap kualitas audit, sehingga semakin independen seorang auditor, maka akan semakin baik kualitas audit yang dilakukannya.

4. Integritas berpengaruh positif terhadap kualitas audit, sehingga semakin baik tingkat integritas, maka akan semakin baik kualitas audit yang dilakukannya.

\section{Keterbatasan}

Meskipun peneliti telah berusaha merancang dan mengembangkan penelitian sedemikian rupa, namun masih terdapat keterbatasan dalam penelitian ini yaitu: Penelitian ini merupakan metode survey menggunakan kuesioner tanpa dilengkapi dengan wawancara atau pertanyaan lisan. Sebaiknya dalam mengumpulkan data, dilengkapi dengan menggunakan pertanyaan lisan dan tertulis.

\section{Saran}

Berdasarkan hasil penelitian yang telah dilakukan, ada bebarapa saran yang dapat dipertimbangkan oleh berbagai pihak:

1. Untuk menciptakan hasil kerja yang berkualitas maka auditor harus meningkatkan kompetensi yang mereka miliki, dengan senantiasa menyampaikan segala temuan, informasi dan data yang diperoleh dalam melakukan audit kepada pimpinan dan pihak yang diperiksa. Jadi dengan hal ini maka proses audit yang mereka lakukan menghasilkan kualitas laporan hasil audit yang 
baik karena ditunjang dengan kompetensi yang mereka miliki.

2. Independensi auditor perlu ditingkatkan agar dalam melaksanakan tugasnya auditor harus bersikap adil dan tidak memihak kepada kepentingan manapun, terutama dalam hal mempertahankan kriteria dan kebijaksanaan kebijaksanaan yang resmi. Sebab jika auditor mengabaikan hal demikian, ia akan kehilangan sikap tidak memihak yang justru paling penting untuk mempertahankan kebebasan pendapatnya. Hal ini sangatlah penting diperhatikan mengingat karena auditor melaksanakan pekerjaannya untuk kepentingan pihak lain.

3. Dengan menyadarai bahwa integritas yang dimiliki seseorang auditor akan mempengaruhi hasil kerja atau kinerja. Maka auditor diharapkan memiliki integritas tinggi sehingga dapat mendorong auditor untuk melaksanakan pekerjaan dengan lebih baik lagi, terutama dalam hal auditor mampu melakukan tindakan yang konsisten dengan nilai dan keyakinan dirinya sebagai auditor

4. Penelitian ini dapat dilanjutkan untuk dapat mengetahui seberapa jauh pengaruh variabel-variabel lain terhadap kualitas audit. Dalam hal ini, variabel-variabel tersebut diantaranya akuntabilitas, pengalaman auditor dan kehati - hatian professional yang sangat diperlukan auditor untuk memberikan opini yang semestinya tanpa kekeliruan dan sebagainya.

5. Diharapkan pada penelitian selanjutnya dalam mengadopsi kuesioner peneliti diharapkan mengembangkan daftar- daftar pernyataan pada penelitian ini. Serta memperhatikan faktor-faktor lain yang dapat mempengaruhi variabel dalam penelitian ini.

\section{DAFTAR PUSTAKA}

Arens, Alvin A, dkk 2011. Jasa Audit dan Assurance. Salemba Empat. Jakarta.

Alim, M.N., T. Hapsari, dan L. Purwanti, 2007, Pengaruh Kompetensi dan Independensi terhadap Kualitas Audit dengan Etika Auditor sebagai Variabel Moderasi, SNA X Makassar, AUEP-08.

Amin Wijaya Tunggal. 2008. Manajemen Audit. Jakarta : Rineka Cipta

Azwar, Saifuddin. 2000. Reliabilitas dan Validitas. Yogyakarta: Pustaka Pelajar. 
Christiawan, Y.J. 2002. "Kompetensi dan Independensi Akuntan Publik: Refleksi Hasil Penelitian Empiris". Journal Directory: Kumpulan Jurnal Akuntansi dan Keuangan Unika Petra. Vol. 4 / No. 2.

Carolita dan Rahardjo. 2012. Pengaruh Pengalaman Kerja, Independensi, Obyektivitas, Integritas, Kompetensi, dan Komitmen Organisasi terhadap Kualitas Audit (Studi pada Kantor Akuntan Publik di Semarang). Diponegoro Journal of Accounting, Volume 1, Nomor 2, Halaman 1-11.

De Angelo, L.E. 1981. " Auditor Size and Audit Quality". Journal of Accounting and Economics: 183-199.

Elfarini, Eunike Christina. 2007. "Pengaruh Kompetensi dan Independensi Auditor Terhadap Kualitas Audit (Studi Empiris pada Kantor Akuntan Publik di Jawa Tengah)". Skripsi S1 FE Universitas Negeri Semarang.

Ghozali, Iman. 2013. Aplikasi Analisis Multivariate dengan Program IBM SPSS 21, Edisi ketujuh, Semarang : Universitas Diponegoro.

Harhinto, Teguh, 2004, Pengaruh Keahlian Dan Indepedensi Terhadap Kualitas Audit Studi Empiris Pada KAP Di Jawa Timur, Semarang, Tesis Maksi, Universitas Diponegoro.

Ilmiyati, Feny dan Yohanes Suhardjo. 2012. Pengaruh Akuntabilitas dan Kompetensi Auditor terhadap Kualitas Audit. Jurnal Akuntansi Vol.1 No.1

Indranata, Iskandar. 2006. Terampil dan Sukses Melakukan Audit Mutu Internal ISO 9001: 2000. Bandung : Alfabeta.

Indriantoro, Nur dan Bambang Supeno. 1999. Metode Penelitian Bisnis. Edisi I Yogyakarta : BPFE

Kusharyanti. 2003. Temuan Penelitian Mengenai Kualitas Audit Dan Kemungkinan Topik Penelitian Di Masa Datang. Akuntansi dan Manajemen (Desember). Hal.25-60

Lasmahadi, A. 2002. Sistem Manajemen SDM Berbasis Kompetensi. www.e-psikologi.com

Mayangsari, S. 2003. "Analisis Pengaruh Independensi, Kualitas Audit, serta Mekanisme Corporate Governance terhadap Integritas Laporan Keuangan”. Simposium Nasional Akuntansi VI Surabaya, 16 - 17 Oktober 2003, pp. 1255-1273.

Mautz, R.K dan H.A. Sharaf. 1993. The Philosophy of Auditing. Sarasota: American Accounting Association.

Mulyadi dan Kanaka Purwadireja. 2002. Auditing. Edisi Kelima. Penerbit Salemba Empat. Jakarta. 
Moizer, Peter. 1997. Auditor Reputation:The International Empirical Evidence. International Journal of Auditing 1 (1). pp.61-74.

Nugroho, Agung, 2005. Strategi Jitu memilih Metode statistic Penelitian dengan. SPSS, Andi Jogyakarta

Purbayu, Budi Santoso, 2005, Analisis Statistik Dengan Microsoft Excel Dan SPSS, Yogyakarta,ANDI.

Rapina, Lili Marlen Saragi, Verani Carolina, 2010, Pengaruh Independensi Ekternal Auditor, Terhadap Kualitas Pelaksanaaan Audit (Studi Kasus Pada Bebebrapa Kantor Akuntan Publik Di Bandung), Akurat Jurnal Ilmiah Akuntansi No. 2 Tahun ke-1 Mei-Agustus.

Reni Amaliah. 2010. Pengaruh Akuntabilitas, Independensi, Integritas dan Kompetensi Auditor terhadap Kualitas Hasil Kerja Auditor. Skripsi. Universitas Negeri Padang

Saripudin. Netty Herawaty dan Rahayu. 2012. Pengaruh Independensi, Pengalaman, Due Professional Care, dan Akuntabilitas terhadap Kualitas Audit. E-jurnal Binar Akuntansi. Vol.1 No.1 (September).

Singgih, E.M., dan I.R. Bawono, 2010, Pengaruh Independensi, Pengalaman, Due Professional Care dan Akuntabilitas Terhadap Kualitas Audit, Simposium Nasional Akuntansi XIII, Purwokerto.

Sunarto, 2003, Auditing, Edisi Revisi Cetakan Pertama, Penerbit Panduan, Yogyakarta.

Sukriah, I., Akram, dan A.I. Biana, 2009, Pengaruh Pengalaman Kerja, Independensi, Obyektifitas, Integritas dan Kompetensi Terhadap Kualitas Hasil Pemeriksaan, Makalah ini dipresentasikan dalam Simposium Nasional Akuntansi XII, Palembang.

Suseno, Novie Susanti. 2013. An Empirical Analysis of Auditor Independence and Audit Fees on Audit Quality. International Journal of Management and Business Studies ISSN. Vol.3 (March).

Sukriah, Ika. Akram dan Biana Adha Inapty. 2009. Jurnal. Pengaruh Pengalaman Kerja, Independensi, Objektivitas, Integritas, dan Kompetensi terhadap Kualitas Audit. Simposium Nasional Akuntansi XII. Palembang.

Sukrisno, Agoes. 2004. Auditing (Pemeriksaan Akuntansi) oleh Kantor Akuntan Publik. Jakarta: Fakultas Ekonomi Universitas Indonesia.

Tugiman, Hiro. 2006. Pandangan Baru Internal Auditng. Yogyakarta : Kanisius.

Tugiman, Hiro. 2006. Standar Profesional Auditor Internal. Yogyakarta : Kanisius. 
Tjun, Lauw Tjun. Elyzabet Indrawati Marpaung dan Santy Setiawan. 2012. Pengaruh Kompetensi dan Independensi Auditor terhadap Kualitas Audit. Jurnal Akuntansi. Vol.4 No.1(Mei) hal 33-56.

Umi, Masruroh. 2010. Faktor-faktor yang Mempengaruhi Kualitas Audit. (Makalah).Semarang : Fakultas Ekonomi Universitas Negeri Semarang.

Wahid Sulaiman, 2004, Analisis Regresi Menggunakan SPSS, Yogyakarta : Andi Offset

Yossi, Seprianti. 2011. Pengaruh Independensi Dan Kompetensi Auditor Terhadap Kualitas Audit, Studi Kasus Auditor KAP di Sumatera Barat.Jurnal.Padang : Jurusan Akuntansi Politeknik Negeri Padang. 